\title{
ENVIRONMENTAL CHANGE BIOLOGICAL RESPONSE
}

\author{
A Symposium organized by the Marine Biological Association and held at the \\ Polytechnic South West in Plymouth, 2-4 April 1990
}

Abstracts of Papers and Posters presented

\section{PAPERS}

\section{Variations in time and space: is biogeography relevant to studies of long-time scale change?}

Angel, M.V. Institute of Oceanographic Sciences, Deacon Laboratory, Brook Road, Wormley, Godalming, Surrey, GU8 5UB

The biogeographical regions in oceanic pelagic environments have been shown to match the large-scale circulation pattern as portrayed by the distributions of water masses. The boundary zones can be hard to define, because advection by mesoscale eddies may carry populations from one realm into another. However, the sedimentary record indicates that, at the height of the last glaciation 18,000 BP the Polar Front had been displaced equatorwards to lie approximately along $45^{\circ} \mathrm{N}$; its present position in the North-east Atlantic is well to the north of Iceland. The Subtropical Convergence was also displaced a few degrees southwards. In remotely sensed images of ocean colour of the North-east Atlantic, a clear boundary zone can be seen in the region of $40^{\circ} \mathrm{N}$. To the north of this boundary, surface chlorophyll concentrations vary greatly from season to season, whereas to the south there are continuously low surface chlorophyll levels. Thus this boundary seems to be associated with a change in the annual production cycle from a highly pulsed seasonal regime on the poleward side, to a more uniform regime with a relatively small seasonal variation on the equatorial side. The mechanism controlling the boundary is likely to be associated with the depth to which winter-time cooling extends, and hence with the re-supply of nutrients into the euphotic zone from deep water.

Re-examination of plankton and micronekton data held in the IOSDL biological database, shows that across this boundary there are also major changes in simple community parameters not only in the pelagic communities but also in the benthos. For example, moving northwards across the boundary, the number of species of planktonic ostracods in each $100 \mathrm{~m}$ sampling stratum from the surface to depths of $2000 \mathrm{~m}$ decreases from around 30 to around 20. Data from several repeat sampling experiments show that species numbers and various diversity indices for the abundant taxa are stable longitudinally and between seasons at mesopelagic depths. At higher latitudes there are changes resulting from seasonal migrations. 
Any long-term shifts in climate will probably lead to shifts in this boundary zone. Since not only do these pelagic communities have time characteristics which are appropriate to the study of decadal change, but they are also remote from direct anthropogenic interference (e.g. pollution and exploitation of living resources), the monitoring of these communities' parameters between 40 and $50^{\circ} \mathrm{N}$ will give an unambiguous indication of when climatic change begins to influence the long-term biological processes. Moreover, since active transport plays an important role in the global cycling of carbon within oceanic waters, and any mismatch between the production cycle and grazing is also significant, predictive models will need to take account of any such shifts of community structure and the concomitant changes in carbon cycling.

\section{Matching of long-term trends in benthic and pelagic communities of the North Sea}

*Austen, M.C., ' 'Buchanan, J.B., *Hunt, H.G., ' Josefson, A.B. \& *Kendall, M.A. *Plymouth Marine Laboratory, Prospect Place, The Hoe, Plymouth, PL1 3DH. ${ }^{+}$Dove Marine Laboratory, Cullercoats, North Shields, Tyne \& Wear, NE30 4PZ. $¥$ National

Environmental Research Institute, Jægersborg Alle 1 B, DK-2920 Charlottenlund, Denmark

Species abundance data for benthic communities, collected during 1971-1988 from the north-east coast of England (western North Sea) and the Skagerrak (eastern North Sea), and pelagic data collected in corresponding areas during 1958-88 by the Continuous Plankton Recorder (CPR) survey have been subjected to multi-dimensional scaling ordination. Changes in community structure at the two benthic stations show a high degree of similarity, characterised by a transition in the late $70 \mathrm{~s}$. Similarly, there is a less marked transition between the 70s and 80 s in pelagic community structure from the eastern North Sea but pelagic data from the western North Sea show no discernible patterns. In the western North Sea macrofaunal abundances and in the eastern North Sea macrofaunal biomass (excluding echinoids and Arctica) appear to co-vary with phytoplankton colour and total zooplankton abundances, although there is insufficient data for statistical testing. A number of factors including eutrophication and/or pollution may be responsible for these changes in community structure.

\section{Ecophysiology of Baltic and Atlantic Fucus vesiculosus L.}

Bäck, S., Collins, J.C. \& Russell, G. Department of Environmental \& Evolutionary Biology, University of Liverpool, PO Box 147, Liverpool, L69 3BX

A sublittoral population of Baltic Fucus vesiculosus and an intertidal population from the Irish Sea have been compared in several aspects of ecophysiology under a wide range of salinity treatments $\left(1.5-102 \%\right.$ ). The populations proved similar in $\mathrm{O}_{2}$ evolution versus photon flux density, having saturation of photosynthesis in $400 \mu \mathrm{mol} \mathrm{m}^{-2}$ $\mathrm{s}^{-1}$. Maximum net photosynthesis of Irish Sea Fucus occurred in 12 and $34 \%$ and that of Baltic Fucus in $6 \%$. Generally, Irish Sea plants were twice as productive as those from the Baltic Sea. 
The ion $\left(\mathrm{Na}^{+}, \mathrm{K}^{+}, \mathrm{Cl}\right)$ contents of Irish Sea plants, consistently exceeded those of Baltic plants. For both populations, $\mathrm{K}^{+}$proved to be the major cation; under hyposaline conditions $\mathrm{K}^{+}$increased with external salinity but was stable in hypersaline solutions. Only Baltic plants showed a decrease in $\mathrm{Na}^{+}$levels under hypersaline conditions. In Irish Sea plants, mannitol concentrations increased with increasing salinity and levels were consistently higher than in Baltic material.

The results show a consistent pattern of differences between the two populations and the status of these is the subject of further investigation.

\section{Clyde sewage sludge disposal - meiofaunal response}

*Bett, Brian J. \& Moore, Colin G. Department of Biological Sciences, Heriot-Watt

University, Riccarton, Edinburgh, EH14 4AS. *Present address: Institute of

Oceanographic Sciences, Deacon Laboratory, Brook Road, Wormley, Godalming, Surrey, GU8 5UB

The impact of sewage sludge disposal at the Garroch Head dump site in the Firth of Clyde on the ecology of meiofaunal populations is assessed. Spatial and temporal variations in community structure attributes have been examined in relation to the level of organic enrichment. This contribution forms an overview of some of the major trends in meiofaunal responses to sewage sludge input.

Each year some $1.5 \times 10^{6}$ wet tonnes of sludge are dumped into the Garroch Head site; as a result of the containment nature of the ground a strong gradient of organic enrichment is produced. Analyses of meiofaunal abundance and composition indicate that this gradient produces a successional response from which the constituent taxa can be classified into sensitive, opportunist and insensitive groupings. More detailed examination of the nematode populations reveals a response that in terms of species richness, abundance and biomass is similar to that typically encountered in macrofaunal studies. A notable departure, however, is the tendency, under conditions of gross organic enrichment, towards larger individual body sizes among the nematodes, and indeed other meiofaunal groups. This aspect of the response is further investigated by reference to shifts in various forms of benthic size spectra.

\section{Responses of the basophilic cells of the digestive gland of mussels to petroleum hydrocarbon exposure}

Cajaraville, Miren P., Díez, Guzmán, Marigómez, Ion A. \& Anglo, Eduardo. Zitologi eta Histologi Laborategia, Biologia Zelularra eta Zientzia Morfologikoen Saila, Zientzi Fakultatea, Euskal Herriko Unibertsitatea, 644 PK, 48080-Bilbo, Spain

A stereological study was conducted on the digestive gland of mussels, Mytilus galloprovincialis Lamarck, exposed to the water accommodated fraction of two crude oils and a commercial lubricant oil (three different concentrations of each). Mussels were sampled after 21, 35, 77 and 91 days exposure and the volume density (VD) of basophilic cells was determined in paraffin sections by a point-counting method. Exposure to petroleum hydrocarbons resulted in a dose-dependent significant increase 
in basophilic cell volume density. This was due to the presence of higher numbers of basophilic cells per digestive tubule, size of basophilic cells remaining apparently unchanged. Results are interpreted in terms of an enhanced epithelial cell regeneration that might be linked to fundamental digestive processes. Indeed, a significant positive linear correlation exists between basophilic cell VD and the percentage of disintegrating tubules.

\section{'Whole organisms'}

Calow, P. Department of Animal and Plant Sciences, The University of Sheffield, Sheffield, S10 2TN

Whole-organism responses to stress can be classified in various ways. Here, I shall distinguish between the proximate responses of individuals and more long-term, adaptive changes. The latter can be classified further into direct physiological responses, that might be either fixed or facultative, and more indirect life-cycle responses. I shall argue that a common theoretical thread can be woven through these various stress responses and, where possible, shall illustrate this with examples involving aquatic (marine and freshwater) organisms.

\section{Evaluation of the mechanisms of resistance to polychlorinated biphenyls (PCBs) in two species of marine diatoms}

Cohen, M.K., West, A.S., Cosper, E.M. \& Wurster, C.F. Marine Sciences Research Center, State University of New York, Stony Brook, New York 11794, USA

Clones of Ditylum brightwellii and Thalassiosira nordenskioldii were isolated from New York coastal waters and PCB-resistance in D. brightwellii was induced in the laboratory by exposure to increasing concentrations of PCBs. Resistance could not be similarly induced in T. nordenskioldii but was serendipitously discovered in cultures which had undergone sexual reproduction.

Cell size of the resistant strains was substantially increased in both species. Larger vacuole space seemed to account for this in D. brightwellii, whereas in T. nordenskioldii larger cells contained more carbon. Tracer experiments with ${ }^{14} \mathrm{C}-\mathrm{PCB}$ indicated PCB accumulation per unit carbon was less in resistant strains of both species. Neutral lipid content per cell, as determined using the fluorophore Nile Red, was similar for resistant and sensitive strains of both species. Sub-cellular examination of lipid droplets in $D$. brightwellii suggested the PCB-resistant strain may be sequestering this lipophilic toxicant in a location removed from physiological activity. In T. nordenskioldii a decreased ratio of neutral lipid:carbon may reduce intra-cellular accumulation of PCBs. These diatom species have developed resistance in the highly PCB-polluted Hudson River estuary and, since they are the preferred food of dominant copepods, may offer less PCBs per unit carbon ration to zooplankton grazers. 
Giving individuals the choice: colonisation as a response to environmental quality

Costello, Mark J. Environmental Sciences Unit, Trinity College, Dublin 2, Ireland

During colonisation studies, community structure may be assessed, using terms such as species (or guild) composition, richness, dominance (or evenness), rank, rarity, stability, abundance, biomass, and the rates of colonisation, decolonisation, turnover and succession. Data are presented in which these terms were used to describe the colonisation of artificial substrata in the marine sublittoral.

It is noted that artificial substrata can now be considered a standard technique in the monitoring of freshwater quality. It is suggested that the potential of colonisation theory and the use of artificial substrata has not been fully realised in assessing the quality of the marine environment.

Giving organisms the opportunity to colonise identical substrata in different areas is effectively an in situ 'choice' test. As such, it may well prove to be a more sensitive measure of environmental quality than traditional sampling methods.

\section{Mink and sea-birds}

Craik, J.C.A. Grendon, Barcaldine, Oban, Argyll, PA34 4AD

Although not traditionally studied by marine scientists, sea-birds are prominent members of marine ecosystems. They are important as potential and actual competitors with man for finite fish stocks, and as indicators of fish abundance and of marine pollution. For many people, their value lies in their aesthetic appeal.

North American mink Mustela vison were imported to Britain in the middle decades of this century to be farmed for their fur. Many escaped, and their wild descendants are now living and breeding along rivers and coasts over large parts of Britain. As their range extends northwards, they pose an increasing threat to the internationally famous sea-bird colonies of Scotland. Examples of predation by mink involving heavy 'surplus killing' at gull and tern colonies in West Scotland will be given. Wider effects of this new and intense form of predation on sea-bird breeding and distribution will be described.

\section{Monitoring the health of the oceans: the role of the CPR in distinguishing natural from anthropogenic effects on the plankton}

${ }^{*}$ Dickson, R.R. \& ${ }^{+}$Colebrook, J.M. *Ministry of Agriculture, Fisheries and Food, Fisheries Laboratory, Lowestoft, Suffolk, NR33 0HT. +Plymouth Marine Laboratory, Prospect Place, The Hoe, Plymouth, PL1 3DH

The post-war CPR and other datasets are used to review the causes of observed longterm changes in the spring and summer plankton of the European Shelf. The effects of changes in strong-wind frequency, water-column stability and nutrient enrichment can each be distinguished according to location and season. The dominant anthropogenic effects appear to be confined to the continental coast of the German Bight with climatic effects dominating elsewhere. 


\section{Long-term population dynamics of fish and crustaceans in the Bristol Channel}

Henderson, P.A. Marine Biology Unit, Fawley Power Station, Fawley, Southampton, SO4 1TW

In 1979 a study of the long-term population dynamics of the inshore community of the Bristol Channel was started. Monthly sampling is still continuing. The data set contains abundance estimates of approximately 80 fish and 20 crustacean species which is almost the complete set of larger animals known to inhabit the region. These data give a unique opportunity to study the longer-term population dynamics of the inshore community. By combining these data with information collected by other researchers, changes in population abundance of many species can be followed for a 20-year period.

Results will be presented to show the inter-relationships in abundance between the commoner species. Particular emphasis will be placed on the variability and resilience of the community and its organisation over the annual cycle. The effect of changes in physical conditions, in particular temperature, will be discussed. Over the last two years there has been a marked increase in sea-water temperature which is linked to major changes in species abundance.

\section{Can trophic diversity help in better understanding the coastal ecosystem functioning?}

Le Bris, H., Majeed, S., Hily, C. \& Glémarec, M. Université de Bretagne Occidentale, Laboratoire d'Océanographie Biologique, Faculté des Sciences, 6 Avenue Le Gorgeu, 29287 Brest Cedex, France

A trophic diversity index (TDI) is derived from the Shannon index, where dominance of each trophic group is based on the total number of individuals belonging to this group.

Variability of the trophic structures of infaunal communities was examined in relation to different sediments on the continental shelf of north-Biscay.

If communities are closely linked to sedimentological conditions, trophic structures are independent because sestonic inputs play a decisive role in such structures.

Trophic structures are fluctuating in time. In muddy areas biogenic modifications and biotic interactions may explain temporal changes observed in trophic structures. Bioturbation due to the presence of subsurface deposit-feeders may accelerate the migration of the RPD layer. Thus it favours the high settlement of surface depositfeeders. The trophic amensalism hypothesis may explain inhibition which may occur between deposit- and suspension-feeders. Stimulated by the modification of the particular material flux, suspension-feeders can monopolize the food resources.

Can trophic structure be interpreted in a successful dynamic way?

In the intertidal zone after an oil-spill the return to normal conditions was accompanied by a successional development towards the dominance of a certain trophic category. Maximum trophic diversity appeared at the first stage of this succession when biomass and abundance are minimum. Then substitution between surface and subsurface deposit-feeders was observed. 
Finally the trophic structure was closely related to predation pressure which may regulate the system from the excessive development of certain species which may monopolize the whole space and food resources. In this case, a minimum diversity index is coupled with a high biomass.

Trophic structures can change in time independently of the abiotic factors and can help to explain the functioning of the coastal ecosystem if the TDI is used simultaneously with the synthetic parameters S, A and B.

\section{Relationship between a drop in sardine and albacore catches and a relaxation of wind speed, tested by a superposed epoch analysis}

Littaye Mariette, Anne. IFREMER, Rue de l'Ile d'Yeu, BP 1049, 44037 Nantes Cedex 01, France

In the north-east Atlantic, in an open ocean area, every summer, a drop of catches of albacore (Thunnus alalunga Bonnaterre 1788) is observed at the beginning of August for 8-10 days. This temporary decrease of catches per unit of effort (CPUE) is related to 5-8 days of relaxation of wind in the previous 8-15 days. A similar and significant relationship is also observed in the Atlantic sardine (Sardina pilchardus Walbaum) fishery in a coastal area in the north-east Bay of Biscay (France). This indicates that a general ecological process is involved in this relationship between wind and CPUE of two pelagic fish, caught at the sea surface.

The timing of the response, for about 15 days, of the sardine and the albacore fishery to a relaxation of wind is interpreted with the help of a productivity model. The lack of wind-driven turbulent mixing provides a progressive decrease of the food chain in the sea-surface layer about seven days after the wind event. Thus, fish disperse and become less susceptible to capture. However, particular fertilization processes are involved at the continental shelf-break. Then, the results of the analysis of the association were not found to be significant for the albacore fishery in this area.

The use of superposed epoch analysis seems to provide a suitable method to analyse such a relationship with a daily time scale. Comparison of these results with those from a cross-correlation analysis used in previous work suggests that further consideration should be given to the use of superposed epoch analysis in fishery science.

\section{Metabolism and toxicity of organic xenobiotics and reduced oxygen species in marine invertebrates}

Livingstone, David R. Plymouth Marine Laboratory, Prospect Place, The Hoe, Plymouth, PL1 3DH

Since their Precambrian/Cambrian origin, animals have been faced with a continual input of toxic foreign compounds (xenobiotics) from food sources, attacks of predators, natural contaminants and, more recently, pollutants. Molecular oxygen is normally converted to water, but partial reduction produces highly reactive oxyradicals. Generation of oxyradicals is enhanced through conditions such as hypoxia and recovery from anoxia, and by interaction with organic xenobiotic metabolism. Central to the defence 
against oxyradicals and xenobiotics is an impressive array of enzymes, and other molecules, which function ideally to detoxify and eliminate them from an organism. The significance of these enzymes is enhanced by their inducibility and by the fact that they metabolize certain xenobiotics to molecular species more toxic, mutagenic or carcinogenic than the parent compound.

Such processes will be reviewed for marine invertebrates, particularly molluscs. Information will be presented on rates of uptake of xenobiotics versus rates of metabolism; qualitative aspects of in vivo metabolism; excretion of metabolites; activities and properties of biotransformation enzymes, particularly cytochrome P-450 and the mixedfunction oxidase system; antioxidant enzymes, oxyradical generation and oxidative damage; induction responses; and genotoxicity. Emphasis will be placed on phylogenetic differences, evolutionary considerations, and examining the findings in relation to the paradigm of mammalian toxicology.

\section{The modification of meiofaunal and invertebrate assemblages associated with the metallic components of industrial waste discharges}

${ }^{*+}$ Newell, P.F., ${ }^{*}$ Trett, M.W., ${ }^{\dagger}$ Newell, R.C. \& $¥$ Maughan, D. ${ }^{*}$ School of Biological Sciences, Queen Mary \& Westfield College, University of London, E1 4NS. ${ }^{+}$Marine Ecological Surveys Ltd, and Land and Freshwater Environmental Services Ltd, PO Box 6, Faversham, Kent. 'Tioxide UK Ltd, Environmental Services, Billingham, Cleveland, TS23 1PS

Annual surveys of meiofaunal and benthic communities from a wide range of marine, freshwater, tropical and temperate receiving waters have been made and the results are reviewed. Multivariate analytical techniques are used to identify and determine impact zones and the high resolution attained is attributed to the detailed examination of the meiofauna.

The shape of the impact zone is dependent, among other factors, on the direction and strength of the current flow and, for low $\mathrm{pH}$ discharges, the buffering capacity and turbulence of the receiving water. The sediments in the impact zone are not abiotic but are typified by a reduced species diversity and an increased abundance of resistant species. These impact zones from point source discharges are remarkably stable and occupy a similar position, and area, in successive years over a 5 year sampling period.

It would seem that these industrial wastes modify the assemblage structure in a similar way to that imposed by natural stress factors.

Analysis of the metal salts in the sediments shows a good correlation between the area defined as the impact zone and enrichment of these sediments by various heavy metals. The loss of certain species in the impact zone seems to be a direct effect by the heavy metals, and those species remaining have elevated sulphur levels, as measured by $\mathrm{x}$-ray micro analysis. It is possible that these high sulphur levels are metalothiones which are employed by these animals to mobilise heavy metals.

Modification of the effluent quality by removing heavy metals would be a strategy to reduce the area of the biological impact zone, which might be a better alternative to disposal than land-fill. 


\section{Detoxification transfer along a food chain}

${ }^{*}$ Nott, J.A. \& ${ }^{+}$Nicolaidou, A. *Plymouth Marine Laboratory, Citadel Hill, Plymouth, PL1 2PB. 'Department of Zoology, University of Athens, Panepistimiopolis, GR 15784 Athens, Greece

It has been observed that the digestive gland of the carnivorous gastropod mollusc, Murex trunculus, does not accumulate the metals which occur in high concentration in the digestive gland of its prey, the detritus-feeding gastropod, Cerithium vulgatum. It is proposed that the mechanisms of metal detoxification which operate in C. vulgatum render the metals biologically unavailable to $M$. trunculus. This scheme is tested by feeding tissues containing detoxified metals from a bivalve, barnacle and gastropod, to a carnivorous gastropod. The metals in the prey are accumulated in insoluble granules which can require elaborate experimental procedures to separate them from the tissue. The structure and analyses of the granules are recorded in the tissue fed to the carnivore and subsequently in the faecal products of the carnivore after passing through the length of the gut. Within these faeces the granules are displayed as remarkably clean preparations. Furthermore, the granules still contain the metals introduced by the tissues of the prey. The observations are recorded by scanning electron microscopy and $x$-ray microanalysis.

This system of detoxification transfer indicates that food-chain progression of material can result in the reduction of the bioavailability of metals. The system does, however, depend upon the capacity and efficiency of the detoxification mechanisms of the initial prey organism.

\section{The Tamar avocets: behavioural responses to environmental change}

Reay, P.J. Department of Biological Sciences, Polytechnic South West, Drake Circus, Plymouth, PL4 8AA

The Tamar estuary is one of four main wintering sites for avocets (Recurvi-rostra avosetta) in the UK and until the early 1970s it was effectively the only one. Numbers in general have increased since 1948 when the first two were noted, and the highest numbers ( $c a$ 200) were recorded during the 1989/90 winter. It is not known specifically where the Tamar birds breed, but throughout their breeding range in western Europe numbers have been increasing, probably in response to increased protection and management of breeding habitat. Useful historical information is available on the Tamar avocets, on both numbers and distribution throughout the estuary complex, but they have been studied in detail for only the last three winters. The information available shows a very restricted distribution, but the areas used for feeding vary between and within years. Such changes in distribution correlate with changes in weather. This correlation is described, and discussed in relation to presumed interactions between the birds, and the biotic and abiotic components of their environment. 


\section{The Plymouth serial observations 1899-1987: their relationship to climatic change and hypotheses of production in the sea}

Southward, A.J., Boalch, G.T. \& Maddock, Linda. Marine Biological Association, The Laboratory, Citadel Hill, Plymouth, PL1 2PB

Fluctuations in species composition and abundance of plankton were noticed in the first years of the Plymouth Laboratory. The early records were qualitative, then during the International Investigations (1902-1907) they were semi-quantitative and accompanied by observations of temperature and salinity covering the whole Channel. Hydrographic observations in the western Channel, including analyses of nutrients and other trace elements, re-started in 1921 and the series on zooplankton and young fish was made fully quantitative in 1924 . These two series refer predominantly to a line of stations from Plymouth out 15 miles to the SSW. Phytoplankton was recorded qualitatively until 1964 when a combined quantitative and semi-quantitative series was started, including ${ }^{14} \mathrm{C}$ estimates of primary productivity. Records of demersal fish and infaunal benthos are at irregular intervals but the rest were maintained monthly (chemistry) weekly (zooplankton) and more frequently (phytoplankton) until 1987 when all the serial observations were stopped.

In the past the major changes have been regarded as providing supporting evidence for a number of hypotheses including (a) control of primary production by intermittent input of 'new' nutrients from the ocean; (b) control of pelagic fish by interspecific competition, with biotic feedback effects on primary production; (c) control of dominant species in the ecosystem by temperature changes. The results of the 70-year series, now seen in hindsight, do show evident effects of climate change on the fauna and flora, which, through biotic interactions, could have influenced the water chemistry; there is little evidence of marked changes in annual primary production in spite of major changes in fauna and flora.

\section{A comparison of methods for analysing changes in benthic community structure}

Warwick, R.M. \& Clarke, K.R. Plymouth Marine Laboratory, Prospect Place, The Hoe, Plymouth, PL1 3DH

Statistical methods for analysing changes in community structure fall under the three general headings of univariate, graphical/distributional and multivariate. These methods are applied to a variety of benthic community data (macrobenthos, meiobenthos, corals, demersal fish), from a variety of localities (intertidal/subtidal, temperate/ tropical) and over both spatial and temporal scales.

Four general conclusions emerge from this comparative study: (1) The similarity between sites or times based on their univariate or graphical/distributional properties is usually different from their clustering in multivariate analyses. (2) Species-dependent (multivariate) methods are much more sensitive than species-independent (univariate and graphical/distributional) methods in discriminating between sites or times. (3) In examples where more than one component of the fauna has been studied, univariate and graphical/distributional methods may give different results for differ- 
ent components, whereas multivariate methods tend to give the same result. (4) Multivariate ordinations of faunistic data have similar configurations to ordinations of environmental data.

A method is described by which the discriminating power (and hence potential causality) of environmental variables can be assessed.

\section{The modification of schooling behaviour in larval sea bass Dicentrarchus labrax, by sublethal concentrations of methyl parathion}

Williams, Madelaine A. 15 Pendarves Street, Beacon, Camborne, Cornwall, TR14 7SQ. Work carried out at: Laboratoire Biologie Marine, Collège de France, Concarneau, France

The species-typical schooling behavioural repertoire of larval sea bass, Dicentrarchus labrax, was examined and described. Experiments were conducted to determine the effects of sublethal concentrations of methyl parathion, an organophosphate insecticide and anticholinesterase agent, on their schooling behaviour. The fish were exposed to $2.50,5.00$ and $10.00 \mathrm{ppm}$ of the toxicant for periods of $2,8,24$ and 48 hours. The results demonstrated distinct modifications in their schooling patterns; there was generally little or no correlation of dosage with period of exposure; deviations in schooling behaviour were maximal and deleterious in fish exposed to $10.00 \mathrm{ppm}$ of methyl parathion. The most conspicuous modification was the deterioration of social attraction and interaction in the three groups of test fish, resulting in statistically significant declines in duration of parallel orientation and frequency of realignment in contrast to the controls. The test fish also exhibited changes in locomotor ability and movements, organization of schools and feeding. Behavioural modifications caused by subacute dosages of methyl parathion may be ecologically significant in the survival of schooling species of fish.

\section{Temperature tolerances of infaunal bivalves and the effect of geographical distribution, position on the shore and season}

${ }^{*}$ Wilson, James G. \& ${ }^{\dagger}$ Elkaim, Bernard. *Environmental Sciences Unit, Trinity College, Dublin 2. ${ }^{+}$Laboratoire de Hydrobiologie, Université Pierre et Marie Curie Paris VI, 12 Rue Cuvier, 75005 Paris

There are four important influences on the temperature tolerance displayed by infaunal bivalves, namely their position on the shore, the depth to which they burrow, their geographical distribution and the seasonal cycle.

The temperature tolerance of a species is closely related to both shore position and burrowing depth, since these both modify the actual range of temperatures to which the organism is exposed and the tidal variation in temperature. As one might expect, southern populations of a species tend to be lower on the shore than equivalents in northern Europe, but at any one location, it is difficult to detect a difference in tolerance between individuals from the top of the shore and those from the bottom. Southern populations do have a higher thermal tolerance than northern, despite the shift in 
littoral distribution. A similar pattern of response and shift in tolerance is shown between summer- and winter-accumulated specimens.

However, the seasonal shift in response to temperature is not entirely as might be expected, as oxygen consumption measurements show reverse acclimation (i.e. winter respiration rates lower than summer). Reverse acclimation has been demonstrated in a number of bivalve species, and the degree of reverse acclimation is here suggested to be related to the degree of deposit- or filter-feeding habit.

There is evidence that bivalves are capable of regulating to some extent their metabolic rate, independent of temperature. Six groups of Macoma balthica were investigated, of which the four from relatively high temperature environments regulated from $20^{\circ} \mathrm{C}$, while the other two did not, suggesting that this capability can be acquired. The implications of these physiological adaptations to temperature are that some poikilotherms are capable of much more sophisticated control of their metabolism in relation to temperature than is widely believed. 


\section{POSTERS}

\section{Ivory Coast and Ghana Sardinella aurita fisheries variations and climatic changes}

${ }^{*}$ Binet, D., ${ }^{\dagger}$ Marchal, E., ${ }^{\dagger}$ Pezennec, O. *Antenne ORSTOM, Centre IFREMER, BP 1049, 44037 Nantes Cedex 01, France. ${ }^{\dagger}$ ORSTOM, Institut Océanographique, Paris, France. ${ }^{\ddagger} \mathrm{CRO}, \mathrm{BP}$ V 18, Abidjan, Côte d'Ivoire

The catches of Sardinella aurita from the Ivory Coast and Ghana fluctuate greatly. In 1972 an exceptional availability led to overfishing and collapse. In 1978, the abundance was restored. Since 1981, the landings have remained at a very high level. This new situation is accompanied by changes in seasons and fishing areas. During the first period, the bulk of $S$. aurita was caught off Ghana, during the upwelling season. In the later years the catches come also from the Ivory Coast, all the year round.

Variability of upwelling and river flows are no longer sufficient to explain the changes in the yield. The rise of fisheries off the Ivory Coast would correspond to the development of a new population, due to a change in the shelf currents.

The hypothesis of an alteration in the current pattern is supported by some direct observations and a set of changes in the tropical Atlantic. (i) A sub-surface salinity maximum spreads out during 1984, in the eastern part of the Gulf of Guinea. It would be the origin of a westwards Guinea undercurrent spreading and intensifying. (ii) The latitude of the ITCZ (Inter Tropical Convergence Zone) affects that of the North Equatorial Counter Current (NECC). The Guinea Current (GC) issues from the NECC. Now, since 1984, the ITCZ has been shifting equatorwards, so an offshore displacement of the GC may be expected.

Over the shelf, the result would be an increase of the westwards advection increasing the loss of Sardinella larvae from the Ghanean shelf, and their retention off the Ivory Coast. Hence, the recruitment of the Ivory S. aurita should rise.

\section{Decline of the dogwhelk, Nucella lapillus, in response to tributyltin (TBT) pollution}

Bryan, G.W., Gibbs, P.E., Pascoe, P.L., Burt, G.R. \& Hummerstone, L.G. Plymouth Marine Laboratory, Citadel Hill, Plymouth, PL1 2PB

Tributyltin (TBT) has been extensively used as a biocide in antifouling paints; consequently concentrations of TBT leachate exceeding $1 \mu \mathrm{g} \mathrm{l}^{-1}$ (1000 pptr) have been measured in some harbour waters. TBT concentrations as low as $1 \mathrm{ng} \mathrm{l}^{-1}(1 \mathrm{pptr})$ induce a genital disorder in stenoglossan gastropods, known as 'imposex'. This phenomenon, now recorded world-wide, causes male sex organs (penis and sperm duct) to develop on the female. Imposex in the European dogwhelk, N. lapillus, is induced by $<1 \mathrm{ng} \mathrm{l}^{-1}$ of TBT in ambient water, and females reared in excess of $5 \mathrm{ng} \mathrm{l}^{-1}$ are sterile because the imposed sperm duct blocks the oviduct preventing copulation and the release of egg capsules. The latter accumulate in the oviductal capsule gland, eventually causing it to rupture, killing the female. Populations close to harbours are thus non-breeding, 
containing no juveniles and proportionally fewer females. Since the dogwhelk is longlived (10+ years) extinction of these populations is a prolonged process but is virtually complete in the Channel coast estuaries of the Helford, Fal and Dart, as well as some parts of Plymouth Sound and the Solent. Dogwhelk development is direct, and in the absence of a planktonic phase, recolonisation of depopulated areas, following the 1987 legislation restricting the use of TBT paints, is expected to take many years.

\section{Seasonal variation in the diet of deep sea echinoids}

\section{Campos, L.S. \& Tyler, P.A. Department of Oceanography, The University, Southampton, $\mathrm{SO} 95 \mathrm{NH}$}

Examination of the gut contents of the deep sea echinoid Echinus affinis from time series samples taken at $2200 \mathrm{~m}$ depth in the northern Rockall Trough show a distinct seasonal variation in the total gut content, amount of organic matter and in the phytoplankton species (as phytodetritus) taken up as a food source. In the winter months both the amount of gut material and total organic matter is low. In the early spring the gut fills with sedimentary material but the organic matter level remains low. The main recognisable material is Foraminifera and coccolith remains. In the late spring and early summer, coincident with the vertical flux of surface-derived phytodetritus the percentage of organic matter increases significantly and the gut contents contain a wide variety of phytoplankton species as well as foram and coccolith tests. During this period there is some evidence that the phytoplankton species are taken up in succession as they appear in the phytoplankton. During the autumn the organic matter content of the gut decreases steadily and the number of phytoplankton species also diminishes. This availability of a labile food source in the late spring and summer provides energy for the development of gametes which show maximum growth rate during this period followed by spawning in January/February of each year.

\section{Biological assessment of the Mersey estuary}

Codling, Ian. Water Research Centre, Henley Road, Medmenham, PO Box 16, Marlow, Buckinghamshire, SL7 2HD

As part of the Mersey Basin Campaign North West Water are investing a large amount of capital in improving the quality of the Mersey estuary. The clean-up programme provides a unique opportunity for studying the effects of improved water quality on the biology of a major estuary.

The objective of this initial part of the work is to provide a quantitative baseline of biological data on sediment and water quality in the Mersey estuary, for comparison with the effects of future improvements.

The work is jointly funded by the Department of the Environment and the National Rivers Authority, North West region.

The quality of both sediment and water quality is being assessed in biological terms at the community and whole-organism levels. The distribution and composition of the sediment-dwelling macrobenthic and meiobenthic communities reflect sediment qual- 
ity while the distribution of suprabenthic animals and the pattern of settlement of planktonic larvae on artificial hard substrata reflect water quality. At the wholeorganism level sediment toxicity is measured by the effects of saline sediment elutrates on the development of oyster larvae. The toxicity of estuarine water and selected inputs to the estuary is being assessed using the same test and an integrated sub-lethal measure of stress is provided by the physiological index, 'scope for growth', in both transplanted and indigenous mussels.

The results to date show a decrease in the diversity of the macrobenthic communities on sandy substrata and hard surfaces from the outer to the inner zones of the estuary. The meiofaunal communities have been shown to be impoverished compared to other European estuaries. Populations of Mytilus edulis, found in large numbers in the outer zone of the estuary, have been shown to be sub-lethally stressed on most of the sampling occasions to date. Mussels transplanted from a clean population have shown sub-lethal stress at all sites after exposure for a period of 30 days.

\section{Annual and interannual changes in benthic populations in the Rockall Trough}

Gage, J.D. Scottish Marine Biological Association, Dunstaffnage Marine Laboratory, PO Box 3, Oban, Argyll, PA34 4AD

The deep sea has previously been viewed as an environment with particularly constant physical conditions and, with its biota, typified as a low-activity ecosystem. However, study of a time series of benthic samples from a $2.9 \mathrm{~km}$ depth permanent station in the Rockall Trough has demonstrated seasonal periodicities in breeding and recruitment among macrofaunal populations and rates of population turnover more similar to those of related species in shallow water than previously thought. Furthermore, comparison of large samples of the seasonally-breeding brittle star Ophiura ljungmani has shown a variability in size structure that is interpreted as reflecting interannual changes in recruitment success. Even more marked changes in year-to-year recruitment success are evident in the sea urchin Echinus affinis studied from a time series at a position further north in $2.2 \mathrm{~km}$ depth. Both species are thought to represent a minority of deep-sea macrofauna with planktotrophic early development.

Although the relationship of the recruitment variability observed to changes in openocean conditions near the surface remains unknown, recent discoveries of annually pulsed organic flux to the deep-sea bed and indications of rapid coupling to the sediment-dwelling biota, prompt a suggestion that long monitoring of these species may provide data relevant to climatic change. Although technically more difficult than monitoring inshore populations, data from such deep-sea species will be unaffected by concurrent changes taking place at more local scales inshore, such as eutrophication. 


\section{Effect of emersion time on feeding and growth of Nucella lapillus (L.)}

Harris, J., Uttley, M.G. \& Wigham, G.D. Polytechnic South West, Drake Circus, Plymouth, PL4 8AA

Juvenile Nucella are known to select prey sizes which maximise their growth rates. However, the evidence for this optimal foraging behaviour comes from continuous immersion systems. In order to extrapolate the feeding behaviour of the whelk into the field we need to know whether the relative value of different prey types varies with tidal level as it affects the degree of aerial exposure.

The feeding and growth of two sizes of juvenile Nucella were monitored for four weeks in a tidal tank giving four levels of exposure ranging from 10-70\% emersion. Four sizes of mussel (Mytilus edulis) were used as prey.

The growth rate of Nucella fell with increasing emersion in each prey and predator size combination. However, the rank orders of prey sizes for the promotion of growth remained broadly the same, although prey values become much more similar at higher levels.

The reduction of growth rate at higher immersion has both a behavioural and a physiological component. First, there is a reduction in the biomass of prey consumed which can be attributed to reduced predation rate; tidal level having no effect on the flesh consumed per mussel. Second, the efficiency of growth is reduced at higher levels. There is a suggestion that the reduction in growth rate is partly attributed to reduced shell growth when the whelks are exposed for long periods.

\section{Whole-body protein metabolism during hyperosmotic adaptation in Mytilus edulis L.}

${ }^{*}$ Hawkins, A.J.S. \& ${ }^{\dagger}$ Hilbish, T.J. *Plymouth Marine Laboratory, Prospect Place, The Hoe, Plymouth, PL1 3DH. 'Department of Biology, University of South Carolina, Columbia, South Carolina 29208, USA

The primary response to environmental salinity changes in osmoconforming marine invertebrates is an active regulation of the intracellular concentration of free amino acids (FAA). By this means, cells are maintained isosmotic with extracellular fluids, and cell volume regulated. Nevertheless, although widespread in many species, the processes effecting changes in FAA concentration, and thus the metabolic costs of such regulation, have been uncertain.

We have used the stable isotope ${ }^{15} \mathrm{~N}$ to help resolve the processes effecting accumulation of FAA during hyperosmotic regulation in the mussel Mytilus edulis. Neither de novo synthesis nor cellular uptake from the haemolymph or external medium could account for major proportions of the FAA accumulated after four days that were required to complete adjustment following transfer from 15 to $30 \%$. Instead, our findings confirm associated evidence that protein catabolism is the main source of FAA, and show that net accumulation was promoted by marked reductions in measured rates both of whole-body protein synthesis and protein loss. 
Previous work has shown that most FAA released to the haemolymph during hypoosmotic change are deaminated, and the resulting ammonia excreted. We emphasize that this loss represents protein nitrogen, which may at least partially explain stress and even mortality with small but regular fluctuations of salinity.

\section{The Continuous Plankton Recorder Survey, 1931-1989}

Hunt, H. Plymouth Marine Laboratory, Prospect Place, The Hoe, Plymouth, PL1 3DH

Since its inception by Sir Alister Hardy in 1931, the Continuous Plankton Recorder (CPR) Survey has provided the international scientific community with its only available monitor of the general state of the oceanic plankton over large space and time scales. Self-contained automatic plankton recorders are towed by ships-of-opportunity along fixed routes at monthly intervals and at a standard depth of $10 \mathrm{~m}$. During the period 1931-89 the ships of 10 nations have towed CPRs along a combined track-length of more than 3.6 million nautical miles in the North Atlantic and the North Sea. This poster explains the operation of the CPR sampling mechanism and shows some examples of the data displays that can be obtained from interrogating the CPR Data Archive.

\section{Responses of estuarine amphipods to long-term exposure to zinc}

Jones, M.B. \& Johnson, I. Department of Biological Sciences, Polytechnic South West, Plymouth, PL4 8AA

The estuarine amphipod Gammarus duebeni was able to colonise the unique environment of a sewage treatment works (Looe, Cornwall) due to an intrusion of saline water which imposes a regular pattern of salinity change (13-34\%o) within the works, similar to the tidal variation of the adjacent estuary. Works amphipods are exposed to elevated levels of heavy metals associated with sewage and, in particular, zinc concentrations are much higher (30-144.5 $\left.\mu \mathrm{g}^{1-1}\right)$ than in the estuary $\left(14-28.5 \mu \mathrm{g}^{-1}\right)$.

Comparison of G. duebeni from the works and the estuary has established the following: (1) Irrespective of salinity, each population regulated total body zinc concentrations to an external threshold of $200 \mu \mathrm{g} \mathrm{l}^{-1}$. (2) Above this threshold, there were salinitydependent (10 and 30\%o) and size-dependent $(10 \%)$ increases in body zinc levels, but no significant inter-populational differences. (3) Survival of works amphipods was higher than that of estuarine amphipods at all zinc/salinity combinations. (4) In the absence of zinc, works amphipods have significantly better osmoregulatory ability than estuarine individuals, particularly in very dilute salinity $(\sim 10 \%)$. (5) Elevated levels of zinc did not affect blood osmolality at high salinity (30\%o), but reduced blood osmolality at low salinity (10\%o); the same response being shown by each population. (6) Cuticle permeability changes were not significantly different between the two populations. 


\section{A comparative study of metallothionein induction and cadmium-binding characteristics in molluscs}

Langston, W.J. \& Bebianno, M.J. Plymouth Marine Laboratory, Citadel Hill, Plymouth, PL1 2PB

Responses of marine organisms to metals differ markedly, even among members of the same phylum, as demonstrated here for molluscs, Littorina littorea, Mytilus spp. and Macoma balthica, exposed to $\mathrm{Cd}$.

Metallothioneins (low molecular weight, cysteine-rich, heat-stable proteins) effectively bind and presumably detoxify a high percentage of $\mathrm{Cd}$ in control and exposed Littorina, though some potentially damaging 'spill-over' to essential high molecular weight proteins is observed with increasing $\mathrm{Cd}$ levels. High metallothionein concentrations, particularly in the digestive gland, appears to be an inherent feature of this species, even at clean sites, and no overall increase in net metallothionein production was observed following exposure to $\mathrm{Cd}$. It seems likely that the primary function of metallothionein in this species involves the regulation of $\mathrm{Cu}$ during the synthesis and catabolism of the respiratory pigment haemocyanin; substitution and detoxification of $\mathrm{Cd}$, though advantageous, may be a fortuitous secondary role.

Metallothionein-like proteins also sequester much of the $\mathrm{Cd}$ in exposed mussels, Mytilus edulis (and M. galloprovincialis). Unlike Littorina however, metallothionein induction appears to be a direct function of $\mathrm{Cd}$ exposure. Since mussels do not possess haemocyanin, a purely detoxifying role for metallothionein seems plausible in this species. Measuring metallothionein-induction in mussels is therefore a potentially valuable means of identifying sublethal response to $\mathrm{Cd}$.

In contrast, metallothioneins are not involved in $\mathrm{Cd}$ metabolism and storage in tellinids, Macoma balthica (and Scrobicularia plana). Cadmium accumulation rates and bioaccumulation potential are considerably lower in these clams than in the metallothionein-producers described above. Paradoxically, therefore, although metallothionein undoubtedly enables molluscs such as Littorina and Mytilus to tolerate an influx of potentially harmful metal, the resulting body burdens may be an order of magnitude higher than in the apparently less Cd-permeable, non-metallothioneinproducing species.

\section{Increased volume densities of haemocytes and pore cells in connective tissue of winkles exposed to sublethal cadmium concentrations}

Marigómez, J.A., Cajaraville, M.P., Soto M. \& Angulo, E. Zitologi eta Histologi Laborategia, Biologia Zelularra eta Zientzia Morfologikoen Saila, Zientzi Fakultatea, Euskal Herriko Unibertsitatea, 644 PK, 48080-Bilbo, Spain

The present experimental study was designed to determine the response to sublethal Cd concentrations of eosinophilic haemocytes and connective tissue pore cells found in the digestive gland-gonad complex of Littorina littorea. These cell types participate in the distribution and storage of $\mathrm{Cd}$ and are also involved in some other key physiological functions. The volume densities of both cell types were estimated in two zones, 
peristomachal and interstitial, of the connective tissue of winkles exposed to $0,0.5$ and $1.25 \mathrm{mg} \mathrm{Cd} \mathrm{l}^{-1}$ sea water through a 27-day experimental period. A stereological method based on point counting was applied with the aid of a Multipurpose Test System graticule (M 168). Point counting was made in five randomly selected fields from up to four non-serial sections. Thus, 20 fields each one comprising $1800 \mu \mathrm{m}^{2}(1100 \mathrm{x}$ total magnification) were examined for each individual. Results indicate that volume densities of the two cell types are increased in both zones studied. Volume densities do not depend on environmental $\mathrm{Cd}$ concentration and exposure-time but higher volume densities are reached more promptly at higher $\mathrm{Cd}$ concentrations. An increase in the numbers of connective cells involved in the detoxification of $\mathrm{Cd}$ (haemocytes and pore cells) is thus a quantitatively demonstrable response of winkles to sublethal $\mathrm{Cd}$ concentrations.

\section{Distribution of mysids in the Tamar Estuary}

Moffat, Angela M. \& Jones, M.B. Department of Biological Sciences, Polytechnic South West, Drake Circus, Plymouth, PL4 8AA

Mysid shrimps occur at very high densities during some periods of the year in the Tamar Estuary and probably form an important link in the estuarine food chain.

The two dominant species in the Tamar, Neomysis integer and Mesopodopsis slabberi, were sampled at approximately monthly intervals during 1989.

The distribution was found to be patchy and the relative distribution of the two species appears to be determined by salinity, with $N$. integer being more common at the lower end of the salinity scale. Size-frequency histograms show a distribution among the life-stages of any individual species which also seems to be related to salinity, although tidal influences are probably involved as well. Some evidence that juvenile stages of $M$. slabberi form separate aggregations is also presented.

The problems involved in quantitative sampling of patchily distributed organisms are highlighted.

\section{Early development of a cryptic, epibenthic community from southwest England}

\section{${ }^{*}$ Rubin, J.A. \& ${ }^{+}$Warner, G.F. *Polytechnic South West, Plymouth, PL4 8AA. ${ }^{+}$Department of Zoology, University of Reading, Reading, RG6 2AH}

A series of panels was exposed in the shallow subtidal, to the south of Plymouth Breakwater, in order to obtain data on times of recruitment and early community development of the cryptic, sessile epifauna found in the area. The first species to settle was the anascan bryozoan Electra pilosa, followed by heavy recruitment of the serpulid Pomatoceros triqueter and then by other bryozoan species. The serpulid became the most abundant animal on the panels, in terms of both number of individuals and percentage cover, as the tubes overgrew all other species present. However, they also acted as a refuge on which subsequent colonisers were able to settle. Multivariate analysis, using number of individuals, suggested that the assemblage had reached an equilibrium after only seven months, although percentage covers of the various species differed greatly from that of small rocks nearby. 
Study of the effect of capture, transport and anoxia on the eel Anguilla anguilla $\mathrm{L}$.

Santos, M.A., Figueiredo, M.R. \& Raposo, F. Department of Biology, University of Aveiro, 3800 Aveiro, Portugal

Yellow eels (Anguilla anguilla L.) with an average weight of $60 \mathrm{~g}$ were caught in January at the Aveiro Lagoon on the Portuguese west coast and kept out of water for four hours.

The blood of the first group of yellow eels was sampled after four hours of anoxia. After a four-hour period of anoxia a second group of yellow eels was put back into aerated water tanks kept with filtered water and its blood sampled after seven days of recovery. The sampled blood was assayed for red blood cell number, haemoglobin, plasma glucose, lactate, total cholesterol, total protein, sodium, potassium and chloride ions.

The results show a highly significant decrease in plasma glucose $(P<0.001)$ and plasma lactate $(P<0.001)$ in the recovery group when compared with the first group of eels kept out of water.

The results show that recovery after a four hour period of anoxia is possible if the yellow eels are transferred and kept in good environmental conditions.

\section{Quantitative responses of Littorina littorea digestive cells and their lysosomal system to salinity changes: laboratory studies}

Soto M., Marigómez, J.A. \& Angulo, E. Laboratorio Citologia e Histologia, Departamento de Biologia, Facultad de Ciencias, Universidad del Pais Vasco, Apartado 644, 48080-Bilbao, Spain

Littorina littorea is an inhabitant of the intertidal zone and hence it is supposed to stand several changes in external salinity conditions. However, previous workers concluded that the digestive gland (probably the digestive gland-gonad complex) was an osmoconformer. Since salinity should then affect digestive cell volume, we planned an experimental design to assess the change in size of this cell type after acclimation to different salinities (100, 75 and 50\% sea water). The results indicate that the digestive epithelium decreases in thickness at decreasing environmental salinities. Therefore, the hypothesis of this organ being an osmoconformer system seems to be meaningless. In order to clarify this controversy some other experiments were carried out to analyse the working of the digestive lysosomal system by stereology after this acclimation, as well as to investigate the response to increasing and decreasing salinities. The results indicate that the digestive lysosomal system acts in cell volume regulation. Unexpected decrease in epithelial thickness is associated with decrease in tubule size, and therefore, it is probably the consequence of water uptake by neighbouring interstitial connective tissue leading to a mechanical pressure on the digestive tubules. Maybe, the lack of osmotic regulatory capability of the interstitial connective tissue accounts for the conclusion reported previously. 
Factors influencing the distribution of free-living marine nematodes in sediments of south-east Cornwall

Surey-Gent, S.C. 10 Horsepool Road, Sheviock, Torpoint, Cornwall, PL11 3EP

A series of multiple-choice feeding experiments was run, using nematodes from three different sedimentary environments. Nematodes showed most attraction for the vitamin B complex, sewage sludge, and organic-rich mud in descending order of preference. Production of $B_{12}$ by sedimentary bacteria can be lost to the system through absorption by detritus and clay minerals. Nematode activity may keep $B_{12}$ in circulation and account for some of the heterogeneous distribution.

In sediment-filled tracks, female nematodes covered greater distances than male nematodes in 24 hours, maximum movement being achieved ( 5 and $12 \mathrm{~cm}$ respectively) when males and females were placed at opposite ends of the same $20 \mathrm{~cm}$ track. When sediment grain-size was changed, actual distances moved reduced, but the overall pattern remained the same.

\section{Theories explaining long term changes in the Southern Ocean ecosystem}

Vuorinen, Ilppo. Finnish Institute of Marine Research, PO Box 33, SF-00931 Helsinki, Finland

Several approaches can be found in theoretical limnology and ecology, in order to explain the large changes found in pelagic ecosystems (e.g. seal and penguin stocks) in the Southern Ocean. The increase of penguin and seal stocks have been explained by decreasing food competition with whales. Competition for food, combined with the size-efficiency hypothesis, can explain the hypothesized increase of krill and accompanying decline of copepods. Furthermore, cascading trophic interaction theories would predict a change in size spectrum of planktonic species as a consequence of a decline in numbers of large predators (i.e. rorqual whales).

In this study changes in the abundance of three dominant copepod species and krill larvae are quantified by combining published results of various Antarctic zooplankton studies. Field studies are performed in order to evaluate the geographical and seasonal variability of zooplankton as well as variation caused by local patchiness and other sampling-related sources of error. Material collected during two expeditions (1988-89 around the Antarctic Peninsula, 1989-90 in the Weddell Sea) is currently being analysed. 